\title{
THE STATUTE OF FRAUDS AND THE PAROL RELEASE OF A MORTGAGE
}

\section{By PaUd Hardin III}

In Stevens v. Turlington, ${ }^{1}$ a North Carolina case, plaintiff, a prospective purchaser of mortgaged premises, went to defendant, the mortgagee, and secured her verbal agreement to release from the operation of her mortgage the land which plaintiff wished to buy. The mortgagee promised to accept in lieu thereof a mortgage on another tract of land. Plaintiff bought the land in question, and a mortgage on the other tract was tendered to defendant. She refused the tender and offered the land at a mortgage sale, where- . upon plaintiff brought an action to quiet title and to restrain defendant from executing a deed of the property. The court held that an unexecuted verbal agreement, made by a mortgagee for a valuable consideration, to release land from the operation of a mortgage is not within the statute of frauds and affirmed judgment for plaintiff.

Again, in Leavitt v. Pratt, ${ }^{2}$ a Maine case, the purchaser of mortgaged land paid his purchase money on the mortgagee's verbal agreement to release the mortgage. The court held the agreement unenforceable as within the statute of frauds, and the mortgagee was allowed to foreclose.

The two cases abstracted illustrate the wide split of authority on the question whether or not a verbal agreement, executed or executory, made by a mortgagee to release his mortgage is enforceable as against the statute of frauds. ${ }^{3}$

No satisfactory theory has been or, it is submitted, can be advanced which will reconcile all of the cases. One suggestion frequently made is that the difference of opinion is based upon the views taken in the various states as to the nature of a mortgage. 4 Supposedly, the distinction is that in some states the mortgagee is considercd as having title to the mortgaged premises, while in others he is considered as having a mere lien or security interest. Follow-

* 2d year law student, Duke University; A.B. Duke University, 1952.

1186 N. C. 191,119 S. E. 210,32 A. L, R. 870 (1923).

$253 \mathrm{Me} .147$ (1865).

${ }^{3}$ See note, 32 A. I. R. 874 (1924), for an excellent review of the decisions.

32 A. I. R. 874 (1924), 49 Ax. JUR. $\$ 202$, p. 528. 
ing through with that theory, a writing is required in the former group of states and not in the latter. This assumes a consistency of attitude which does not exist in either title or lien theory states. ${ }^{5}$ Jones has listed North Carolina as a "title" state and Oklahoma and Oregon as "lien" states;" yet, the North Carolina court does not require a writing, ${ }^{7}$ while those of Oklahom ${ }^{8}$ and Oregon ${ }^{9}$ do require a writing for the release of a mortgage. In commenting on this inconsistency one text writer said:

"'The North Carolina court 'adheres to' the title doctrine, at the same time arguing that the mortgagee's 'title' is not such an interest in realty as to require a writing for its retransfer to the mortgagor. The title or lien label, as has appeared and will appear, is neither wholly without meaning nor wholly without influence on decisions. But its significance and effect can be grasped only by exact analysis from case to case and from state to state.' 10

Another theory has been advanced to the effect that an unexecuted agrement to release a mortgage is within the statute but an executed release is not within it. ${ }^{11}$ However, as one court has pointed out, the cases cited by Corpus Juris in support of that theory are most unsatisfactory, ${ }^{12}$ and many of the cases which have held that a writing is not necessary involved an unexecuted agreement to release. ${ }^{13}$ This theory, then, is also untenable.

In the early English case of Richards v. Syms, Syms borrowed money of Richards and gave a mortgage securing his bond. A few

- This has been most graphically illustrated by a review of the random remarks of the North Carolina Supreme Court in Sturges and Clark, Legal Theory and Real Property Ifortgages, 37 YALE L. J. 691, 710 et seq. (1928).

' 1 Jones Montaages, $\$ \$ 49,52,53,67$ (8th ed., 1928).

7 Hemmings v. Doss, 125 N. C. 400, 34 S. E. 511 (1899); Stevens v. Turlington, 186 N. C. 191,119 S. E. 210,32 A. T. R. 870 (1923); Hare v. Hare, 208 N. C. 442,181 S. E. 246 (1935).

${ }^{8}$ Oklahoma Farm Mortgage Co. v. Cesar, 178 Okla. 451, 62 P. 2d 1269 (1936).

' Union Central Life Insurance Co. v. Toliver, 152 Ore. 185, 52 P. 2 d 1129 (1936).

${ }^{10}$ Hanna, Gases and Materials on Secubitry, p. 541 (2d ed., 1952).

${ }^{11}$ Malins v. Brown, 4 N. Y. 403 (1850); 27 C. J. $\$ 201$, p. 218, notes 57, 59 ; 37 C. J. S. 118 , p. 611 , notes 92,94 .

12 Degheri v. Carobine, 100 N. J. Eq. 493, 500, 135 Atl. 518, 521 (1927).

${ }_{13}$ Hemmings v. Doss, supra, note 7; Stevens v. Turlington, supra, note 1; Hare v. Hare, supra, note 7; Riley v. Atherton, 185 Ark. 425, 47 S. W. $2 d 568$ (1932); Schweider v. Lang, 29 Minn. 254, 13 N. W. 33, 43 Am. Rep. 202 (1882). 
years later Richards told Syms to take back the writings, that he freely forgave the debt. Richards died and his heir brought a bill against Syms to compel him to pay the debt or to stand foreclosed. The court, in holding that the evidence of the parol forgiving of the debt was admissible despite the statute of frauds, said in part:

"But where a mortgage is made of an estate, that is only considered as a security for money due, the land is the accident attending upon the other; and when the debt is discharged, the interest in the land follows of course. In law the interest in the land is thereby defeated, and in equity a trust arises for the benefit of the mortgagor." "14

This case has been widely followed in this country, thus giving rise to a third theory. As Professor Williston expresses it:

"The distinction between a transfer of land by operation of law and by act of the parties is important also in relation to contraets to discharge encumbrances. A contract to pay a debt or to accept payment by way of accord and satisfaction, or otherwise, is not within the Statute, though the effect of such payment may be to discharge a mortgage, and thereby transfer an interest in land to the mortgagor. On the other hand, an express promise by a mortgagee to surrender or discharge his mortgage, insofar as this involves anything more than accepting payment of the debt, is within the Statute. Whether a contract by a mortgagee to discharge a mortgage means anything more in a particular case than a contract to accept satisfaction of his debt is a question of interpretation. ..."'15

This theory of release by operation of law might well explain a large number of cases. However, release agreements have been held not to be within the statute even though the debt remains outstanding, ${ }^{16}$ and even in cases in which the debt was satisfied the courts have not been content to rest their decisions on operation of law. ${ }^{17}$

Logically, there can be no doubt that a release of a mortgage or a contract to release a mortgage is within the statute of frauds. A

14 Barn. Ch. 90, 93, 27 Eng. Repr. 567, 568 (1740).

152 Wiliston, Contracts, 492, p. 1420 (rev. ed., 1936).

10 Hemmings v. Doss, Stevens v. Turlington, Hare v. Hare, supra, note 7 ; Ackla v. Ackla, 6 Pa. 228 (1847).

${ }^{17}$ In Riley v. Atherton, 185 Ark. $425,426,47$ S. W. $2 d 568$ (1932), the court did not mention operation of law but used instead this broad languago: "'in this and in many other states a mortgage is considered as security for tho debt merely and not the principal obligation. An oral agreement to satisfy; therefore, does not fall within the statute of frauds." 
mortgage is a conveyance of an interest in real property within the meaning of the statute of frauds, and a contract to give a mortgage is a contract for the sale of an interest in real property within the meaning of the statute. ${ }^{18}$ The logical corollary to that statement is that the release of a mortgage is a conveyance of an interest in real property within the statute of frauds, and a contract to release a mortgage is a contract for the sale of an interest in real property within the statute. There in an abundance of authority for that position, ${ }^{19}$ and, indeed, it seems so obviously true that the Massachusetts court was prompted to remark:

"We are called on to enjoin against the use of a mortgage deed, by verbal proof that the respondent had given up his estate. The proposition is self-evidently false. "200

If the purpose of the statute of frauds is to prevent frauds and perjuries, is it to be supposed that it was intended to prevent evilly disposed persons from swearing into being a non-existent mortgage, or contract to mortgage, and yet not to prevent evilly disposed persons from swearing into being a non-existent release, or agreement to release?

Despite the apparent logic and respectable authority favoring the view that the release of a mortgage is within the statute of frauds, it is doubtful that there is a single fact situation for which there is no authority favoring the contrary proposition. Indeed, in what would appear to be the numerical majority of cases the

${ }^{18}$ Sleeth v. Sampson, 237 N. Y. 69, 142 N. E. 355, 30 A. L. R. 1400 (1923).

${ }^{10}$ Dodson v. Protective Iife Ins. Co., 236 Ala. 111, 181 So. 492 (1938); Hunt v. Maynard, 6 Pick. 489 (Mass., 1828) ; Parker v. Barker, 2 Mete. 423 (Mass., 1841) ; Duff v. United States Trust Co., 327 Mass. 17, 97 N. E. 2d 189 (1951); Leavitt v. Pratt, 53 Me. 147 (1865); Joseph S. Naame Co. v. Louis Satanov Real Estate \& Mortgage Corporation, 103 N. J. Eq. 386, 143 Atl. 531 (1928) ; George V. Meinersmann, 119 N. J. I. 460, 197 Atl. I (1938); Oklahoma Farm Mortgage Co. v. Cesar, 178 Okla. 451, 62 P. 2d 1269 (1936); Union Central Life Ins. Co. v. Toliver, 152 Ore. 185, 52 P. 2 d 1129 (1936); Merrill v. Pease, 51 Vt. 556 (1878).

${ }^{20}$ Eunt $\mathrm{v}$. Maynard, supra, note 19. The writer of one law review article has criticized the Massachusetts court for depending merely upon the selfevidency of the proposition and failing to answer the contention that the mortgage was extinguished by operation of law. Appel, Parol Release of a Mortgage, 42 Dick. L. REv. 226, 230 (1938). The answer is that in the Massachusetts case, the debt by the parol agreement, was to remain in full effect and only the mortgage was to be discharged. Hence, it was not even an appropriate case for the application of the operation of law concept. The error of the law review writer emphasizes the importance of case to case examination and the fallibility of attempting to cover the whole field with a single theory. 
courts have held on one theory or another that an agreement to release a mortgage, executed or executory, need not be in writing.

One of the devices employed by a few courts has already been referred to. In many cases the agreement to release has been accompanied, preceded, or followed by payment or other satisfaction of the debt. That circumstance opens the way for the courts to adopt the operation of law theory and say with the Mlinois court: "The payment or discharge of the debt, evidenced by the notes, operates to release the mortgage, which is but an incident to the debt." 21 This theory has been analogized by Professor Williston to the view which seems to be almost universally accepted in this country that the assignment of the debt by the mortgagee takes with it the mortgage, which is but an incident to the debt and caunot stand alone. $^{22}$ The theory seems tenable enough; but, as we have seen, it can be applied only in those situations in which the debt is satisfied.

In those courts which hold that a release is within the statute of frauds it may frequeutly be taken out of its operation by the doctrine of part performance. An illuminating casc is Olikhoma Farm Mortgage Co. v. Cesar. ${ }^{23}$ There the promise to release was made to third parties who intended to purchase parts of the mortgaged property from the mortgagor. The agreement was enforced in favor of the purchaser who paid part of the purchase price to the mortgagor in reliance on the mortgagee's promise and entered and made improvements. It was not enforced in favor of the purchaser to whom the same promise was made and who made improvements, but who did not pay any of the purchase price. In the New York case of Malins v. Brown ${ }^{24}$ precisely the same agreement was involved, and the court held that payment by the purchaser of the purchase money and his being let into possession were suffcient to take the case out of the operation of the statute. It would seem, then, that in a jurisdiction which recognizes the doctrine of part performance a purchaser who has paid part of his purchase money and gone into possession stands in a fair way to escape the statute of frauds.

Another means of enforcing a parol release or agreement to release is the rather nebulous doctrine of equitable estoppel. Certain factors being present, it is said, the mortgagee is estopped to

21 Mutual Mill Ins. Co. v. Gordon, 121 Ill. 366, 375, 12 N. E. 747, 750 (1887).

${ }^{22}$ Wilisiston, op. cit. supra, note 15.

${ }^{23}$ Supra, note 8.

24 Supra, note 11. 
set up the statute of frauds. Just what these factors are is involved in some mystery. One court said by way of dictum that the doctrine is applicable any time a purchaser buys land from a mortgagor, relying on the mortgagee's promise to release that land from the operation of his mortgage. ${ }^{25}$ A Pennsylvania case has apparently gone so far as to indicate that actual reliance is not necessary, it being enough to say that the purchaser might reasonably have relied on the promise. ${ }^{26}$

Finally, a few courts have held, quite apart from any doctrine of operation of law, part performance, or equitable estoppel, that the release of a mortgage is not within the statute of frauds. In Stevens $\nabla$. Turlington ${ }^{27}$ a parol promise to release was enforced. The debt was not paid, so the operation of law concept would be of no avail. Under the cases we have considered on part performance the requisite elements might have been present, but the court made no mention of that doctrine. Equitable estoppel was the subject of one brief paragraph of the opinion, but the court did not indicate that the decision turned on that principle. North Carolina is a title state, ${ }^{28}$ so any argument to the effect that a mere lien can be released without a writing would be of no avail. The court discussed in detail the nature of a mortgage and concluded that:

"... until foreclosure, or at least until possession is taken, the mortgage, as a general rule, is regarded in the light of a chose in action, to be dealt with according to the principles of equity."

Ackla v. Ackla, a case in which the court also talked equitable estoppel, was decided on the same ground as the North Carolina case. The Pennsylvania court in the Ackla case said that a mortgage is simply

". . a chose in action extinguishable by a parol release, which equity will execute as an agreement not to sue, or by turning the mortgagee into a trustee for the mortgagor. "30

The reasoning of the courts which hold unequivocally that the release of a mortgage is not within the statute of frauds seems to be merely that the mortgage is only the security for the debt and

\footnotetext{
${ }^{25}$ Stevens $\nabla$. Turlington, supra, note 1.

${ }^{20}$ Ackla $\nabla$. Ackla, supra, note 16.

27 Supra, note 1 .

${ }^{28}$ JoNES, op. cit. supra, note 6.

${ }^{20} 186$ N. C. $191,195,119$ S. F. $210,212,32$ A. L. R. 870,873 (1923).

${ }^{30} 6 \mathrm{~Pa} .228,230$ (1847).
} 
not the principal obligation; so, dogmatically, its release or discharge need not be in writing. ${ }^{31}$ The argument seems fairly adequate as applied to the cases in which the debt is paid, ${ }^{32}$ but saying that a mortgage is but the incident of the debt and is extinguished with the debt by operation of law would seem to be quite different from saying that a mortgage is but the incident of a debt and can be released by parol though the debt remains outstanding.

The only conclusion which reasonably can be drawn from examining the cases involving the statute of frauds and the parol release of a mortgage is that the application of the statute in a given situation is a matter of free decision. The notions at large in the cases, operation of law, part performance, and equitable estoppel, are notably indefinite, and they cross-cut one another in a way that baffles prediction. Broad language is often used which gives the appearance of settled law in a number of states. But the cases are not numerous, and they usually leave ample room for making fact distinctions in the future. Ample authority exists both for applying and for not applying the statute in any probable situation. In the law of security relationships any lack of certainty is presumably a defect. However, in these cases, we may guess there is a compensating virtue in flexibility and the supple handling of the debatable policy underlying the statute of frauds.

Most of the cases centering around the problem of the parol release of a mortgage are of rather early vintage. Two recent cases will demonstrate that the courts are today no nearer agreement on principle or result than ever.

In the Massachusetts case of Duff v. Onited, States Trust Co., mortgages covered a tract of land divided into lots, on each of which a house was proposed to be built. Allegedly, the defendant bank, as mortgagee, orally agreed to release each lot as sold, if the buyer would place a new mortgage with the bank, insured with the Federal Housing Administration. The court held that the agreement, if made, was unenforceable, as it was a contract for the sale of lands and thus within the statute of frauds.

In the California case of Benavides v. White, ${ }^{34}$ plaintiff, a judgment creditor of one Trowler, wished to satisfy his judgment out of property owned by Trowler, of which property Trowler had exe-

${ }^{31}$ See Riley v. Atherton, supra, note 17.

${ }^{32}$ Southerin v. Mendum, 5 N. H. 420 (1831).

${ }^{33} 327$ Mass. 17, 97 N. E. $2 d 189$ (1951).

34 94 Cal. App. $2 d$ 849, 211 P. $2 d 597$ (1949). 
cuted a deed of trust to defendant. In consideration of plaintiff's oral promise to pay to defendant the six hundred-dollar debt owed him by Trowler, defendant orally agreed to cancel the deed of trust. Relying on the promise plaintiff levied against the property incurring expense. Defendant then refused to carry out the deal. Judgment was affirmed for plaintiff. The opinion of the court consumed only a few lines of print; its sole rationale was that the evidence seemed to support plaintiff's contention that "no agreement for the sale of a trust deed is involved." The court made no further explanation of its decision, succumbing, as it would appear from the concluding sentence of the opinion, to an understandable temptation to avoid entirely this tough problem:

"It would serve no useful purpose to recite all of details; it is sufficient to note that a review of the record reveals sufficient evidence to support the judgment and the statute of frauds, in the light of the trial court's view of the evidence, does not apply."35

35 94 Cal. App. 2d 849, 850, 211 P. 2d 597, 598 (1949). 